$$
\text { ベンガラのアートと科学の間で }
$$

\author{
堀石 七生 \\ 戸田エ業侏東京ヘッドオフィス，テ 105-6123 港区浜松町 2-4-1，世界貿易センタービル $23 \mathrm{~F}$.
}

\title{
A Historical Survey of Bengala in View of Art and Science
}

\author{
Nanao Horiishi \\ Toda Kogyo Corp., Tokyo Head Office, World Trade Center BLDG. 2-4-1 Hamamatsu-cho, Minato-ku, Tokyo 105-6123.
}

Received August 8, 2002

\section{SYNOPSIS}

Iron oxide pigment is commonly called Bengala in Japan. The name did not originate from old Japanese language, but from Portuguese. In this paper a historical survey of Bengala is given from ancient age to the present days. Bengala was one of the earliest coloring pigments used by human beings and still has its important roles in our modern life. It has been well known that in ancient ruined caves animals were drawn on the rocks by using natural iron oxide pigments. Red colored bricks in the old Indus civilizations ( 4500 years ago) were made from red clay. In ancient China (about $2^{\text {nd }}$. Century A.C) magnetic iron oxide was first applied to Direction Indicating Tools so called Shinan-gyo. In the present days, Bengala has been one of the most important materials in modern industries, especially electronics. From now on, Bengala would give the solutions to serious problems, i.e. recycling natural resources, earth environment preservation and energy saving which are the important key words in the $21^{\text {st }}$ century.

\section{KEYWORDS}

Bengala, iron oxide pigments, recycling natural resources, earth environment preservation, energy saving

\section{1 はじめに}

酸化鉄顔料 (ベンガラ*1) は古くて新しい工業材料である. 人類は有史以前から歴史を刻んで来た. 考古学の研究成果 がそれを証明している．即ち，発掘された遺跡や埋蔵品には 古の人々のその時代その地方における生活文化が描かれてお り，それらの洞窟画や石室内部に描かれた絵に用いられた着 色顔料には,酸化鉄顔料が多用されていたことが各種の測定 分析の結果から知られている. 絵の具や記録のルーツ及び伝 承すると言う人間の思考は有史以前からのものであった.

人類はまた，未来への夢と憧れを抱きながら歴史を築いて 来た. 科学の進歩がそれを証明している.この科学の進歩に も人類は酸化鉄を利用して来た。

\footnotetext{
*1)ベンカララは, 旺文社発行の古語辞典によるとオランダ語[Bengala]でンド のベンガルに産し．(1黄味を带びた赤色粉末染料．紅殸．(2)「弁柄綿」の 略.「弁柄系」はベンガラつむきを織る木綿の系で「唐系」とも云い, ベン ガルから輸入したのでベンカラと云った.「弁柄縭」は䋛絽織りのベンカラ つむぎ、これらの言萧は元禄時代,井原西鶴の浮世草子や置土産等の作中 て用いられていた事が記されている。但し，オランタ語辞典には[Bengala] なる語は無く, ポルトカル語辞典にある. 語源の所以とした。
}

例えば, 4500 年前のインダス文明においては赤土を焼成し た赤レンガが使用されおり，この佬成レンガはセラミックス の元祖*2)である.また，紀元 2 世紀頃の中国では磁鉄鉱( マ グネタイト)を用いた「指南魚」と言う方位を指し示す道具が 発明されており，15世紀末の大航海時代をもたらした羅針盤 の元祖である.

17世紀頃にはオランダの東インド会社がベンガル湾を経由 して日本へ渡来し，種々の舶来品をもたらした．この舶来品 を総称して「ベンガラ」と称したが, 酸化鉄顔料の国産化が 開始した18世紀ころから，舶来品の高級品をイメージして酸 化鉄顔料をベンガラと呼ぶようになったものと思われる。こ こでは,この歴史的な呼称に親しみを込めて酸化鉄顔料をべ ンガラと呼ぶことにする.さて,20世紀は18世紀の産業革命 で萌芽した工業の近代化とそれを支えた科学基盤を発展させ て飛翟的な工業化学の進歩と経済の高度成長を達成した.こ

\footnotetext{
*2)「長江文明発捅記」(文芸春秋平成 14 年 4 月号)には，インタス文明上り䦽 か 2 千年昔の中国の当該遗跡から $600^{\circ} \mathrm{C}$ 以上の温度で均一焼成した赤レン カかが出さし，歴史の害き换えが話題となっている。
} 
の20世紀においてもベンガラは重要な工業材料として貢献し た.即ち,エレクトロニクスを支えるフェライトコア材,フェ ライト磁石材, 磁気テープを初めティスクやカード等の磁気 記録材，電子印刷用磁気卜ナ一材，その他枚挙にいとまがな いほど各種用途の原料として, ベンガラは様々な酸化鉄粉に 変身を遂げながら活用されてきた.ところで，21 世紀のキー ワードは「資源, 環境, エネルギー」であると言われている が，同時にこれらは前世紀からの動脈産業がもたらした資源 の枯渴, 環境破壊等と言う莫大な負の遺産の象徵でもある. ベンガラはこの課題にも挑戦している. 即ち，資源のリサイ クルとリユース，大気污染や水質污濁等環境を破壊する公害 を防止する対策並びに自然環境の保全のために，ベンガラ及 びその合成技術が成果を挙げている. 筆者はこのベンガラに 心を寄せて 40 年間, 「ベンガラの化学と工業」をテーマに取 り組んできた者であるが,ここでは歴史の間にベンガラを垣 間見ることにより，アートと科学に対してベンガラが果たし た役割を検証した。

\section{2 歴史に見るベンガラの役割}

2.1 アルタミーラ洞窟から高松塚古填, そして近代へ

酸化鉄 $\left(\alpha-\mathrm{Fe}_{2} \mathrm{O}_{3}\right)$ は人類文化史上で最も古い着色顔料であ り，その特徵はその時代その地方の生活文化の歷史を今日に 伝える記憶材料であったことである．即ち，スペインのアル ターミラやフランスのクーニャック洞窟の岩壁に画かれてい る太古の動物画にも，古代エジプトのピラミッド，中国の雲 崗石窟, 敦煌莫高窟, インドのアジャンター石窟や日本の高 松塚古墳などの石室内部に施した装飾壁画にも，また，地中 海の海底から引き上げられた古代ギリシャのエーゲ海文明を 彷彿とさせる声や皿などの陶磁器に施された彩色絵にも, 赤 色褐色の酸化鉄が用いられていたことか確認1)されている。 この圚重な人類の文化遗産を風化させることなく今日に伝え ることが出来たのは, 酸化鉄が有する化学的安定性によるも のである. また酸化鉄顔料が古来より多く重用されたのは, 天然に豊富に産出して資源的に恵まれていたこと，赤色が信 仰上のシンボルカラーであったことにも起因していたと考え る. 他方, 酸化鉄は地球の生誕から現在に至るまでの地球の 歷史を記憶している地質工学上でも大変有用な記憶材料で あった。即ち，酸化鉄には種々結晶構造が異なるものが存在 しており，それらは地球創生のドラマの中から地には種々結 晶構造の異なるものが存在しており, それらは地球創生のド ラマの中から地中や地表の環境変化により生成した鉱物とし て Table 1に示す物が知られている.特にこれら酸化鉄鉱物の 磁性は地磁気の変遷を記憶しているので, 現在の地球地理を 解明する上で有用であるとされている。

酸化鉄赤色顔料は日本においても古くから使われていた. 縄文・弥生時代には土器類の着色顔料として, 古境時代には 横穴装飾古墳の壁画の彩色顔料として用いられていた.これら は赤土に含まれた天然の酸化鉄であった.飛鳥・奈良時代には 仏教の伝来と共に, 寺院や仏像などの造形美術に種々の赤色
着色材料が用いられていたが, 朱(硫化水銀HgS), 鉛丹(酸化鉛 $\mathrm{Pb}_{3} \mathrm{O}_{4}$ )並びに酸化鉄 $\left(\alpha-\mathrm{Fe}_{2} \mathrm{O}_{3}\right)$ 顔料は中国からの到来物であった. オランダの東インド会社による海外交易が盛んに行われた 17 世紀ころには，黄土 ( $\alpha-\mathrm{FeOOH}$ を含有した土)を焼いて赤 色 $\left(\alpha-\mathrm{Fe}_{2} \mathrm{O}_{3}\right)$ 化した土を精製して得られた酸化鉄顔料「ベンガ ラ」が輸入されるようになると，日本各地の神社仏閣並びに， 染料や化粧用紅粉として重用された.この当時, 舶来品ベン ガラは大変高価な品物であったが, 18世紀初め上質な国産べ ンガラが製造された頃には，商家や民家の大黒柱蚛格子戸等 の木材防腐と着色のために膠をバインダーに用いた塗料とし て, また, 輪島梁り等の漆器類の着色や陶磁器の絵付け等の 工芸用に多用され，酒井田柿右衛門の赤絵陶磁器は東インド 会社の交易船により有田からヨーロッパにもたらされ大きな インパクトを与えた.

2.2 国産化は銅山から，そして鉄鋼業から

ベンガラの国産化は 1707 年に岡山県の備中吹屋下谷(現在 の岡山県川上郡成羽町吹屋)から始まった. 同地方は銅山で栄 えていたが採掘される銅鉱石には硫化鉄鉱を多く含有してい た.この副生硫化鉄鉱は野積みで廃棄され風雨に晒され, や がて田畑や河川を污染する厄介物となった. ある時,この厄 介物が赤い粉に変化しているのを偶然見付けたことから,こ の廃棄硫化鉄鉱から硫酸鉄結晶を精製し,これを焼いて赤色 ベンガラを製造する方法(ロー八法と呼んだ)を開発して, 初

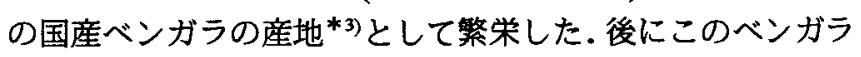
を当地の名に因んで「吹屋ベンガラ」2)と呼んだ. 1700 年代の 半ば頃に大阪で鉄屑を原料とした「鉄丹ベンガラ」の製造が 始まったが, 品質は吹屋ベンガラに遠く及ばなかったので 1700 年代末には衰退した.

吹屋ベンガラは品質が優れていたので全国的に隆盛を極め, その製造技法を手本として硫化鉄鉱が産出した各地で生産が 盛んになった.ここで特筆すべき事は,この吹屋ベンガラの 製造技法は 1970 年 12 月に「大気污染と水質污濁等公害防止 に関する施行法」が成立する迄の, 実に 270 年間もの長い間 受け継がれ，実施されてきたベンガラ $\left(\alpha-\mathrm{Fe}_{2} \mathrm{O}_{3}\right)$ 製造の基本技 術であったと言うことである.このロー八法の技法は後に開 発された「湿式合成法」に対して「乾式合成法」と呼んだ.

明治維新後の日本は文明開化の掛け声の下に海外の技術導 入に力を入れた. その代表は製鉄技術であり，洋式の溶鉱炉 を導入したことにより粗鋼生産量は飛躍的に增大した.

製鉄産業の隆盛は鉄製品の用途を拡大し鋼板の需要を增大 したが,一方では鋼板の酸洗工程から鉄分を含んた酸性廃液 を多量に排出したので公害問題を生じた.この当時, 鋼板の

*3) 文献2)の記録によると借中吹屋は岡山県中西部の吉備高原にあり,古来, 中 国山地の砂鉄の㝸散地としての拠点であった。吹屋銅山の始まりは非常に 古いが, 近世に入り吉网銅山と改名した. 1700 年代には西国一の名銅山と なり，これを有てた泉屋吉左衛門は後に四国の別子銅山を発見し，住友の 祖となった. 明治初頭には三授の祖となった岩猗弥太郎が吉岡銅山の経営 に当り，明治末頃には日本の三大銅山の一つに数えられる迄になった。昭 和 47 年閉山した。吹屋ベンガラの歴史もまた,この吉岡銅山の栄枯盛衰の 歴史と奇しくも同し道を歩み，昭和 47 年に 270 年の歴史に幕を閉した. 
酸洗には硫酸が用いられていたので廃液中には鉄イオンと未 反応の硫酸が含まれていた。そこで先ず，この廃液に鉄屑を 投入して硫酸と鉄居とを反㐫させることにより廃液の硫酸鉄 濃度を高濃度化した後に, 鉛張りの冷却槽で硫酸鉄 $\mathrm{FeSO}_{4} 7 \mathrm{H}_{2} \mathrm{O}$ を結晶化して回収する方法で廃液を処理した。

また, 1938 年頃から国産化が開始したチタン白 $\left(\mathrm{TiO}_{2}\right)$ 産業 においても原料であるイルミナイト鉱 $\left(\mathrm{FeTiO}_{3}\right)$ は $\mathrm{Fe}$ 分を $\mathrm{Ti}$ 対して等モル含有していたので，硫酸を用いてイルミナイト 鉱からT诚分を抽出する工程からは多量の硫酸鉄廃液が排出 した.この廃液の鉄分は硫酸鉄 $\mathrm{FeSO}_{4} 7 \mathrm{H}_{2} \mathrm{O}$ 結晶として回収さ れたが, 廃液には原料に由来する $\mathrm{Fe}$ 以外の多種類の金属成分 を多量に含有していたので, 回収硫酸鉄にも異種金属を不純 物として含有していた。

これら副生硫酸鉄はべンガラの鉄原料として使用したが， 吹屋の硫化鉄鋼から得た硫酸鉄原料のロー八と区別して,「人 工硫酸鉄」と呼んだ.

この頃のベンガラ工業は, それまでの山里深い鉱山から採 れるロー八を鉄原料にしていた吹屋から，やがて，近代工業 加ら大量に副生する人工硫酸鉄を原料とし，生産設備の近代 化による大量生産型の近代化学工業へと脱皮して行った.し かし，生産設備や技術が近代化しても乾式法の基本 (吹屋の ローハ法)は変らなかったので,大量生産と同時にこの乾式法 が基本的に内包していた問題即ち，硫酸鉄結晶を焙焼する際 に発生する $\mathrm{SO}_{3} や \mathrm{SO}_{2}$ 等の排ガスによる煙害及び焼成後の製 品水洗工程からの排水による河川の水質污濁等の公害問題か 一気に噴出した。この乾式法は1971年の公害防止条例の施行 により 270 年の歴史に幕を閉じた。

2.3 製法の無公害化と近代工業への展開

1960 年代半ばにベンガラの無公害製造法)が開発された.

この方法は,人工硫酸鉄を水に溶解した硫酸鉄水溶液を原料 に，これに苛性ソーダ等のアルカリを添加して水酸化第一鉄 $\mathrm{Fe}(\mathrm{OH})_{2}$ コロイド水溶液を調整し(式 1-1), この水溶液を加熱 しながら酸化する(式1-2)ことによりマグネタイト $\mathrm{Fe}_{3} \mathrm{O}_{4}$ 粒子 を沈殿し，

$$
\begin{aligned}
& \mathrm{FeSO} \mathrm{O}_{4}+2 \mathrm{NaOH} \rightarrow \mathrm{Fe}(\mathrm{OH})_{2}+\mathrm{Na}_{2} \mathrm{SO}_{4} \\
& \mathrm{Fe}(\mathrm{OH})_{2}+\mathrm{Na}_{2} \mathrm{SO}_{4}+1 / 2 \mathrm{O}_{2} \rightarrow \mathrm{Fe}_{3} \mathrm{O}_{4}+\mathrm{Na}_{2} \mathrm{SO}_{4}
\end{aligned}
$$

この粒子を精製(水洗, 加熱酸化等の工程)(式1-3)して, 赤 色酸化鉄 $\alpha-\mathrm{Fe}_{2} \mathrm{O}_{3}$ 粉とする方法である。

$$
2 \mathrm{Fe}_{3} \mathrm{O}_{4}+1 / 2 \mathrm{O}_{2} \rightarrow 3 \alpha-\mathrm{Fe}_{2} \mathrm{O}_{3}
$$

この方法は，煙害の $\mathrm{SO}_{\mathbf{x}}$ ガスを発生しない，水洗工程の排 水も中性で沈殿物を含まないので，無公害な製造法である. 水溶液中で合成するのでこの酸化鉄顔料の製造方法を，先に 示した「乾式法」に対して「湿式法」と言う. Fig.1は， $\mathrm{Fe}(\mathrm{OH})_{2}$ コロイド溶液の濃度及び第一鉄に対するアルカリの添加当量 比 $(\mathrm{R})$ と酸化温度との関係において,生成する酸化鉄の種類を 示す状態図であり，湿式合成法の基本 ${ }^{4}$ である。

湿式合成法は公害対策のみならず, Table 1の各種酸化鉄粒
子を製造することができるので各種工業分野に用途を広めて いった。

この湿式合成法の基礎となった技術は，1958年当時，日本 電気株式会社が研究開発していた世界最高の通信用 $\mathrm{Mn}-\mathrm{Zn}$ フェライトであるネフェライト用高純度酸化鉄の開発( 昭和 33 年頃) の成果に原点があった。この詳細な開発経緯は，ネ フェライト開発者の明石雅夫代ご自身が本紙に回顧録ら)とし て記載されている通りである。

ベンガラは着色顔料として長い歴史の顔を持っているが， 1930年代にフェライト磁石が発明され，そして磁気記録テー プが発明されたことにより，着色材料から転身して磁性材料 の顔のも持つようになり, ベンガラは広義の酸化鉄粉へと成 長し，交通，道路や建築等公共分野並びに，住宅，自動車や 家電製品等個人消費製品分野へと市場を進展しながら，ベン ガラの無害性と安価であることを特徵にして需要を拡大して 行った.しかし，同時にルスナー法*4)やアニリン法*5)からの

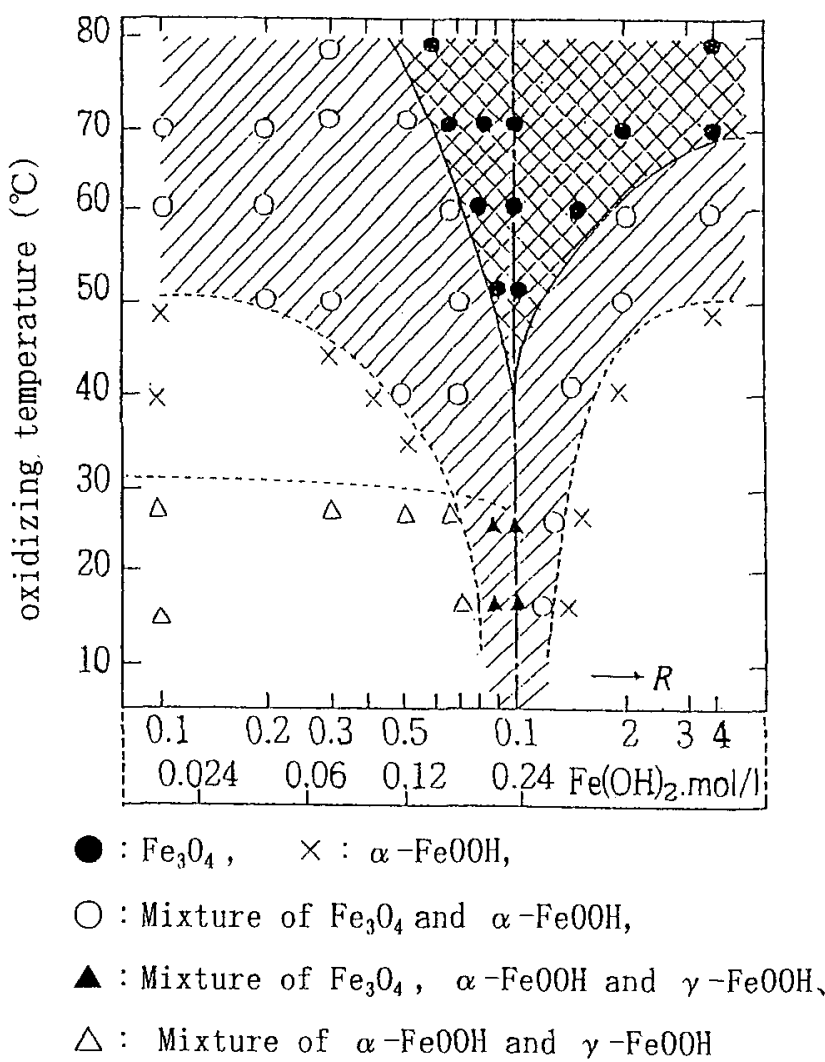

Fig.1 The phase diagram relating to oxidation conditions of $\mathrm{Fe}(\mathrm{OH})_{2}$ aqueous colloidal suspension and a kind of compositions (by Dr. M. Kiyama).

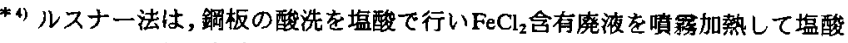
$\mathrm{HCl}$ 回収する方法であるが，結果として酸化鉄 $\alpha-\mathrm{Fe}_{2} \mathrm{O}_{3}$ を副生した.この 酸化鉄粉什着色顔料としては特性不足で,専らフェライト用原料として使用 されている.この方法の他に,ルルギー法, ドラボー法, ピースリバー法, 石川島大同法,ケミライト法等があるが,最も広く実用化されているのがル スナー法である。

*3) 染料や香料になるアニリン $\left(\mathrm{C}_{6} \mathrm{H}_{5} \mathrm{NH}_{2}\right)$ 工業において，原料の二トロベンゼン $\left(\mathrm{C}_{6} \mathrm{H}_{5} \mathrm{NO}_{2}\right)$ 鉄と塩酸を用いて還元する製造工程加ら酸化鉄粉が副生する. これをアニリン副生ベンガラと呼んだ. 
Table 1 A kind of iron oxides and hydroxides.

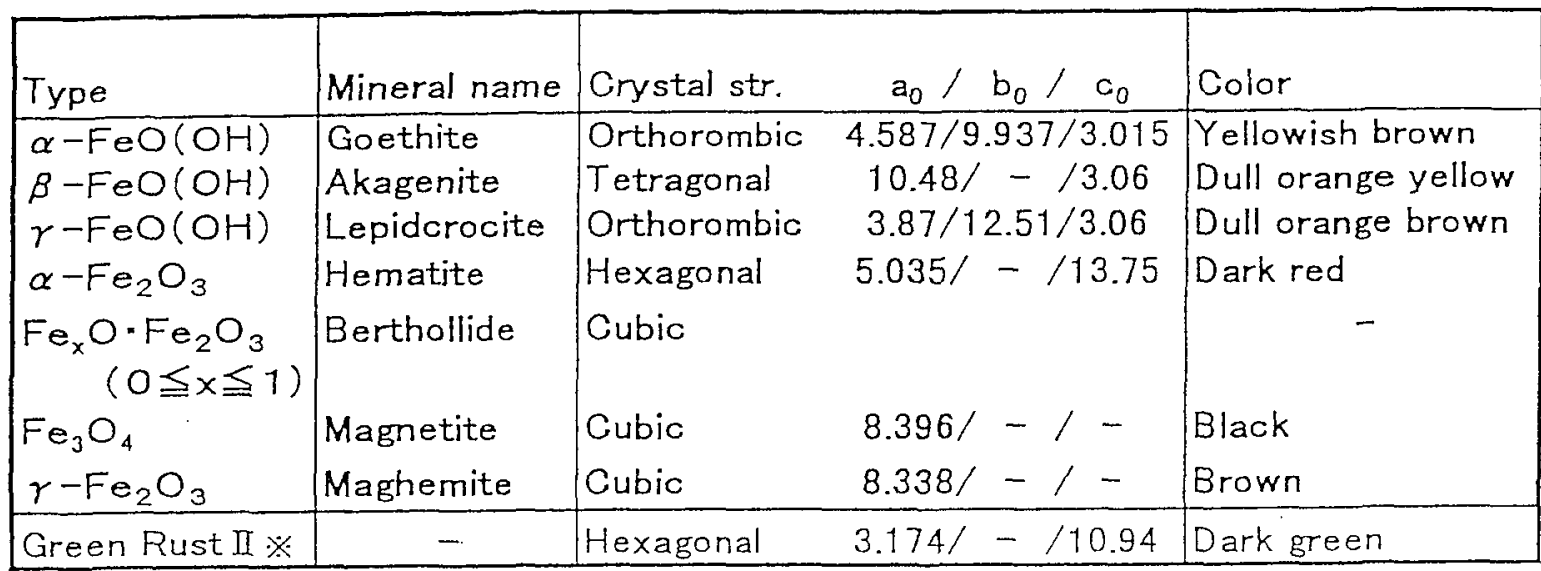

※basic salts containing ferrous and ferric ions.

副生酸化鉄粉の増大，並びに原料硫酸鉄が枯晹する等の困難 な問題も多く発生し多難な時代を迎えた。

\section{1 世紀への取り組み 環境と酸化鉄の化学}

21 世紀のキーワード「資源・環境・エネルギー」と関連し て考察すると, 酸化鉄粉には注目すべき機能がある.ここで は生活環境の改善に役立つ酸化鉄並びに酸化鉄合成技術を応 用した実例を示した。

3.1 重金属含有廃水を浄化する $\mathrm{Fe}(\mathrm{OH})_{2}$ コロイドの化学

化学工業並びに大学や研究所の実験室から排出する廃液に は有害金属を含むものがあり，河川や海水を污染するので公 害防止対策がそれそれ義務付けられた。

酸化鉄湿式合成法を応用して，重金属を含有する廃液に鉄 塭と苛性ソーダを添加して，廃液中の全金属イオンに対して

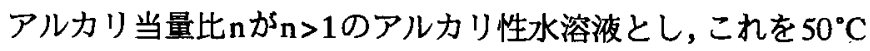
以上の温度に加熱しながら空気を吹き込むことにより全金属 イオンを沈殿させると, 廃液中に含有しているFeにより重金 属類がフェライト化する．この現象により廃液から有害重金 属成分を分離除去する方法で，フェライト化法と称して実用 化した。

Table 2 には処理前後の廃液成分を比較して示した. 3.2 燃焼を促進する酸化鉄ナノ粒子

硫酸第一鉄水溶液に炭酸アルカリ水溶液を添加すると炭酸 鉄 $\mathrm{FeCO}_{3}$ コロイドが生成する.この $\mathrm{FeCO}_{3}$ コロイド溶液を加熱 しながら空気を吹き込んで酸化すると反応条件により， $\alpha-\mathrm{FeOOH}$ 及び $\mathrm{Fe}_{3} \mathrm{O}_{4}$ ナノ粒子が生成する.これを炭酸鉄コロイド法と呼 ぶ.この方法で得られた酸化鉄ナノ粒子粉は化学活性が大き く，特に酸化または還元性雾囲気下で $300^{\circ} \mathrm{C}$ 以上の温度にお いて，酸化鉄が還元或いは酸化される際に，周辺雾囲気を自 ら放出または吸収する酸素により, 酸化性或いは還元性雾囲 気にコントロールすると言う機能を発揮することを見出した. この機能に着目して生活ゴミや産業廃棄物を焼却する際に焼 却炉から発生するダイオキシンの抑制効果について詳細に検
Table 2 Concentration of metal ions influent and effluent.

\begin{tabular}{|c|c|c|}
\hline \multirow{2}{*}{ Metal } & \multicolumn{2}{|c|}{ Concentration } \\
\cline { 2 - 3 } & Influeunt $(\mathrm{mg} / \mathrm{l})$ & Effluent $(\mathrm{mg} / \mathrm{l})$ \\
\hline $\mathrm{Hg}$ & 7.4 & 0.001 \\
\hline $\mathrm{Cd}$ & 240 & 0.008 \\
\hline $\mathrm{Cu}$ & 10 & 0.01 \\
\hline $\mathrm{Zn}$ & 18 & 0.016 \\
\hline $\mathrm{Cr}$ & 10 & $0.01>$ \\
\hline $\mathrm{Ni}$ & 1000 & 0.2 \\
\hline $\mathrm{Mn}$ & 12 & 0.007 \\
\hline $\mathrm{Fe}$ & 600 & 0.06 \\
\hline $\mathrm{Bi}$ & 240 & 0.1 \\
\hline $\mathrm{Pb}$ & 475 & 0.01 \\
\hline
\end{tabular}

討した》.

この酸化鉄活性の機能原理を Fig.2に示した.* (TIC 戸田工業(侏)の商品銘である).

ダイオキシン発生のメカニスムは，プラスチック類を含む ゴミを焼却する際に，焼却炉中に未燃焼部分があると先ず， $400 \sim 500^{\circ} \mathrm{C}$ でダイオキシンの前駆体が発生し，600〜700 $\mathrm{C}$ 付近でダイオキシンを合成する.さらに燃焼温度が上昇して $900^{\circ} \mathrm{C}$ 以上になるとダイオキシンは再分解する.そこで, $900^{\circ} \mathrm{C}$ 以上の高温度で常時ゴミを燃やしつづければ焼却炉からダイ オキシンは発生しないことになる. 行政が実施方を指導して いる対策はこの方法を基本としたものである。

しかし，この対策は毎日大量のゴミが発生する大都会で， 大規模焼却炬で処理できる地域では実施が可能であろうが， ゴミ排出量が少量な地域や小規模焼却炉に対しては現実的で はない．小規模ゴミ焼却炬でもダイオキシン発生を防止でき る対策が必要である。

Fig.2の対策方法によれば $300 \sim 400^{\circ} \mathrm{C}$ の比較的低温度にお 


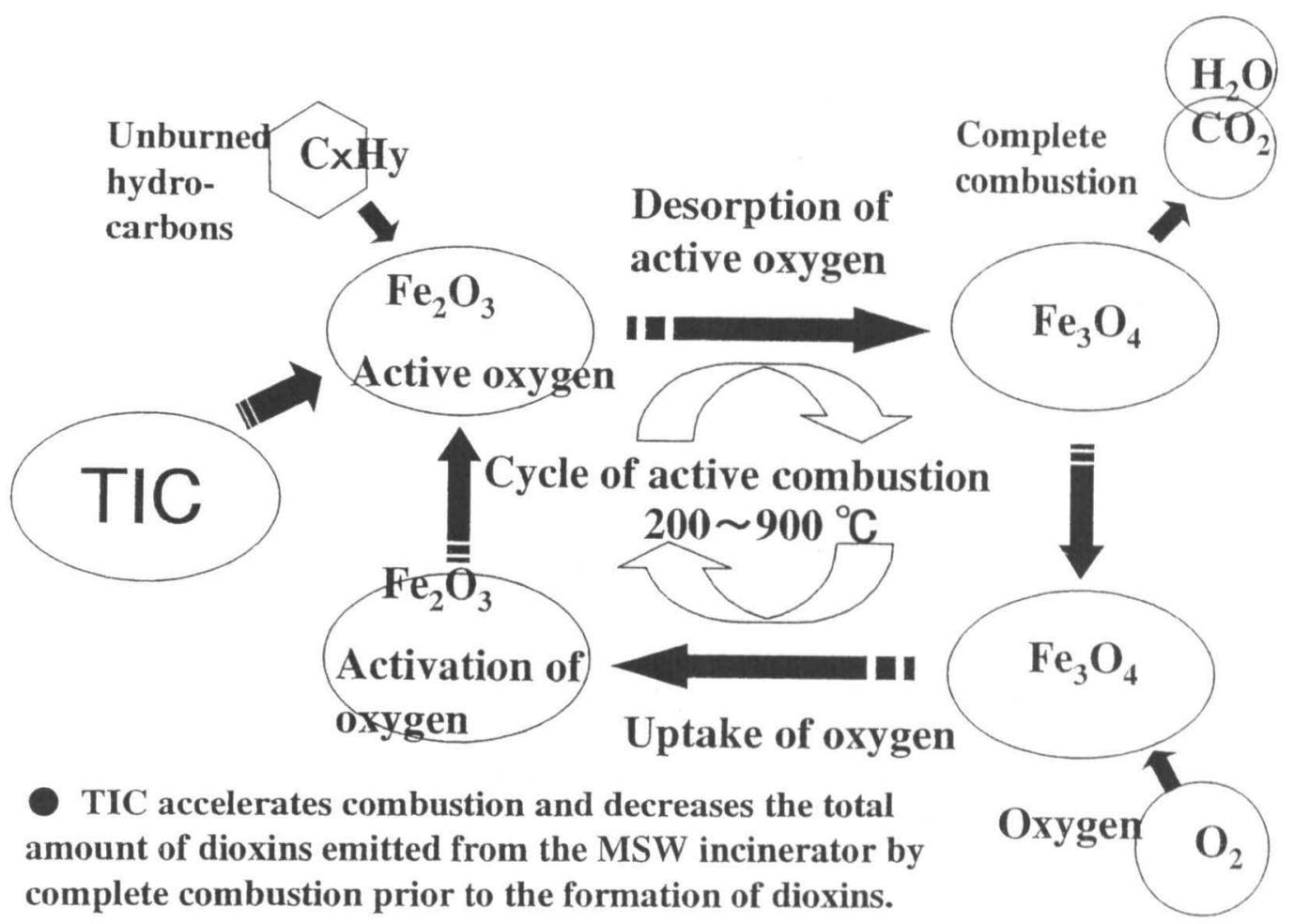

Fig.2 TIC ${ }^{@}$ cycle for activating combustion.

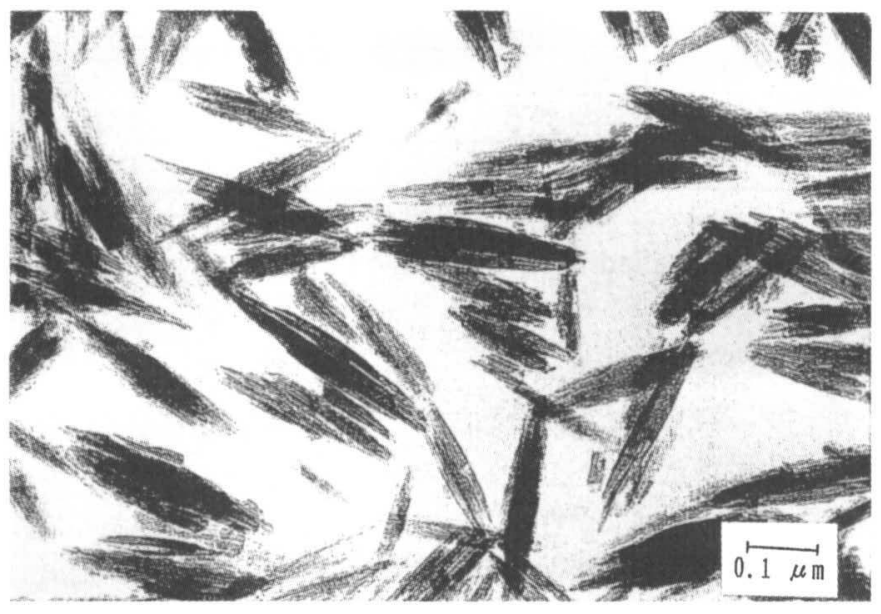

Fig.3 A EM-photograph of $\alpha-\mathrm{FeOOH}$ particles TIC ${ }^{@}$.

いて, 酸化鉄 $\mathrm{Fe}_{2} \mathrm{O}_{3}$ は未燃焼ガス成分により還元されて $\mathrm{Fe}_{3} \mathrm{O}_{4}$ となり，未燃焼物 $\mathrm{C}_{\mathrm{x}} \mathrm{H}_{\mathrm{y}}$ は, この酸化鉄粒子が還元して発生す る活性酸素により完全燃焼して $\mathrm{H}_{2} \mathrm{O}$ と $\mathrm{CO}_{2}$ となるので, ダイ オキシンは発生しない.一方, 酸化鉄 $\mathrm{Fe}_{2} \mathrm{O}_{3}$ が還元されて生成 した $\mathrm{Fe}_{3} \mathrm{O}_{4}$ は生成と同時に炉内雾囲気が酸化性となるので,酸 化して再び $\mathrm{Fe}_{2} \mathrm{O}_{3}$ となる.このようにして酸化鉄粒子はゴミの 燃焼を促進してダイオキシンの発生元である前駆体 $\mathrm{C}_{\mathrm{x}} \mathrm{H}_{\mathrm{y}}$ を消 滅させることによりダイオキシンの発生を根元から遮断する 効果を発揮する。

実用化した酸化鉄ナノ粒子粉TIC ${ }^{\circledR}$ は炭酸鉄コロイド法によ り生成したもので, 比表面積が $80 \sim 100 \mathrm{~m}^{2} / \mathrm{g}$ のナノ粒子粉で
ある.TIC @の粒子形態を Fig.3に示した.

下記は実用の実績形態の一例である.

* 回収用ゴミ袋: ポチエチレンやポリプロピレン樹脂にTIC ${ }^{\circledR}$ を数％含有させたゴミ袋やレジ袋等のエコ製品に関する 特許を取得して実用化した.この特許は発明協会平成 12 年度地方発明表彰にて特許庁長官奖励賞を受賞した. ま た,このエコ製品は平成 12 年 10 月現在, 27 市 154 町村の 自治体で採用されている.

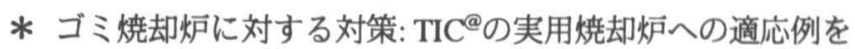
Fig.4に, 原理実証の実績例を Table 3に示した. 平成 14 年 12 月からはダイオキシン規制に関する恒久対策法が施行 されるので, 種々の対策方法が提案されているが, 現在の ところダイオキシンの発生を根元から根絶する対策は本方 法以外には無い。

3.3 ボイラー排ガスから炭酸ソーダを合成

酸化鉄ナノ粒子TIC @の合成に用いる炭酸ソーダは, 排煙脱 硫装置を転用してボイラーの燃焼排ガスと苛性ソーダ水溶液 との気液接触反応により合成して用いている.これにより, 工場敷地内に発生する炭酸ガスの総量を抑制することができ, 地球温暖化問題に配虑した対策となった.

下記に実施の一例を示す.

*使用した苛性ソーダ溶液

: 18 規定液

*吸収した重油ボイラーの燃焼排ガス量 : $4.2 \mathrm{Nm}^{3} / \mathrm{hr}$

*生成液の炭酸ソーダ濃度 ： $5.6 \mathrm{~g} / \mathrm{ml}$

この実績は品質及び経済性において産業上十分有効であり, 同時に, ボイラーからの燃焼排ガスは浄化され, 炭酸ガスは 


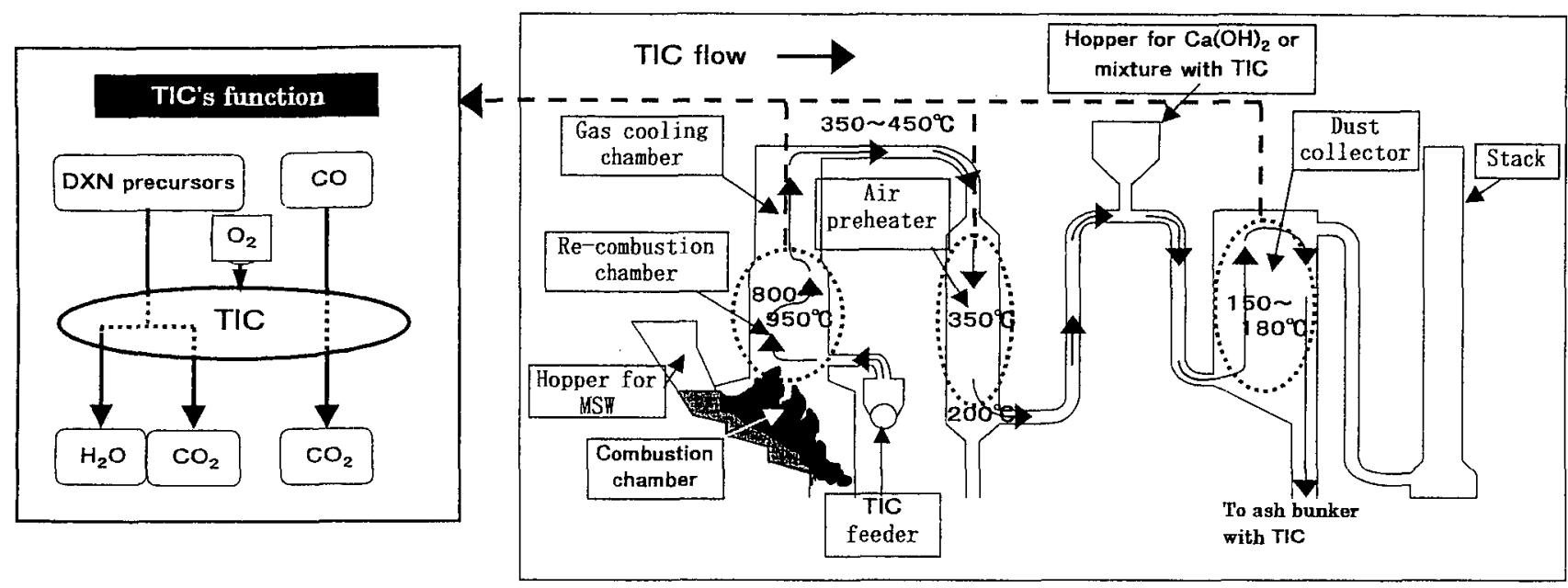

Fig.4 A schematic flow of an incinerator applied to TIC@.

Table 3 The results of demonstrative experiments at operating public incineration facilities using TIC ${ }^{\circledR}$.

\begin{tabular}{|c|c|c|c|c|c|c|}
\hline \multirow[t]{2}{*}{ Name of exsiting incineration facility } & \multicolumn{2}{|c|}{ Type of incinerator } & \multirow[t]{2}{*}{ Dust collector } & \multirow{2}{*}{$\begin{array}{c}\text { Legal } \\
\mathrm{DXN} \text { regulation } \\
\left(\mathrm{ng}-\mathrm{TEQ} / \mathrm{Nm}^{3}\right) \\
\end{array}$} & \multicolumn{2}{|c|}{$\begin{array}{c}\text { DXN concentration } \\
\left(\mathrm{ng}-\mathrm{TEQ} / \mathrm{Nm}^{3} \text { ) }\right.\end{array}$} \\
\hline & Type & Capacity & & & Control & Using TIC \\
\hline Akasaka town,Okayama prefecture & Mechanized batch & $6 \mathrm{t} / 8 \mathrm{~h}$ & $\mathrm{BF}$ & 10 & 19 & 2.8 \\
\hline A town, Hyogo prefecture & Semi-continuous & $30 \mathrm{t} / 16 \mathrm{~h}$ & EP & 10 & 10 & 1.7 \\
\hline B town, Okayama prefecture & Mechanized batch & $10 t / 8 h$ & EP & 10 & 18 & 2.5 \\
\hline C town, Hokkaido & Mechanized batch & $20 t / 8 h$ & EP & 5 & 8.7 & 1.5 \\
\hline D town, Okayama prefecture & Mechanized batch & $20 \mathrm{t} / 8 \mathrm{~h}$ & $E P$ & 5 & 27 & 1.3 \\
\hline RDF boiler facility, Shimane prefecture & Mechanized batch & $32 t / 8 h$ & $M C+E P$ & 5 & 15 & 1.3 \\
\hline
\end{tabular}

Concentrations of dioxins emitted from incinerators can stably be decreased down to below $5 \mathrm{ng}-\mathrm{TEQ} / \mathrm{Nm}{ }^{3}$ by using TIC.

炭酸ソーダに固定化されると言う大気污染防止の大きな波及 効果を併せてもたらした。

\section{4 ま とめ}

17世紀頃，オランダの東インド会社が交易船で織物やつむ ぎを織る唐系等と共に赤色粉末染料や化粧用紅として酸化鉄 顔料を日本にもたらした，当時これら舶来品を総称して「べ ンガラ」と呼んでいたが, ポルトガル語辞典によれば, ベン ガラBengalaとはインドのベンガル地方を指す言葉であり酸化 鉄顔料と言う意味は無い.しかしその当時，インド湾をベン ガル湾と呼んだように，同地方を経由して到来した物をベン ガラと呼んだものと肯ける.18世紀頃に着色用酸化鉄顔料が 国産化されるようになるとこの酸化鉄顔料を舶来高級品のイ メージで「ベンガラ」と呼ぶようになり，今日では「ベンガ ラ」と言えば酸化鉄顔料を指すようになった。

本文は日本のこの伝統的な呼び名となった「ベンガラ」に 親しみを込めて，ベンガラの文明史上での役割について検証 したものである.

ベンガラは适か6000年以上も前から現代に至る文明におい
て，アートと科学に深く関係して来たことを証した. 今日の 高度に成長発達した20世紀文明の光と影においても, ベンガ ラは変容を遂げながら「古くて新しい工業材料」であり続け た.また 21 世紀の将来を展望して, 資源の枯渴, 自然環境の 保全や省エネルギー等の問題解决に対しても，ベンガラには 有望で絶大な機能性があることを示した．しかし，紙面の制 約で言及できなかた多数の取り組み課題, 例えば, IT化社会 への対応，ナノテクノロジーやバイオサイエンスへの対応等 であるが,これらについては稿を改めることにした。

本文を通して, 一人でも多くの方々にベンガラの魅力を観 取して頂けたならば筆者の法外な喜びである.

\section{文 献}

1) 馬㴊久夫, 富永健編: 考古学のための化学 10 章, 東京大学 出版会, (1981).

2) 備中吹屋 : 山陽新聞サンブックス,(1997).

3) 堀石七生, 蔵田文男: 日本国特許第 773657 号.

4) M.Kiyama: "Conditions for the Formation of $\mathrm{Fe}_{3} \mathrm{O}_{4}$ by the Air Oxidation of $\mathrm{Fe}(\mathrm{OH})_{2}$ Suspensions", Bull. Chem. Soc. Jpn., 47 
(1974)1646-1650.

5) 明石雅夫: "ネフェライト", 粉体および粉末治金, 48(2001) 869-876.

6) 堀石七生: "磁性酸化物記録媒体の開発と動向 ", 粉体およ
び粉末冶金, 42(1995)685-689.

7) 今井友之, 松井敏樹, 藤井泰彦, 沖田朋子, 中井資: " ヘマ タイト触媒によるクロロベンゼンおよびベンゼンの接触酸 化 ", 日本化学会誌, No.8(2000)541-545. 